\title{
In situ-RT and immunolaser microdissection for mRNA analysis of individual cells isolated from epilepsy-associated glioneuronal tumors
}

\author{
Jana Fassunke ${ }^{1}$, Michael Majores ${ }^{1}$, Claudia Ullmann ${ }^{1}$, Christian E Elger ${ }^{2}$, \\ Johannes Schramm ${ }^{3}$, Otmar D Wiestler ${ }^{1}$ and Albert J Becker ${ }^{1}$ \\ ${ }^{1}$ Department of Neuropathology; ${ }^{2}$ Department of Epileptology and ${ }^{3}$ Department of Neurosurgery, University \\ of Bonn Medical Center, Bonn, Germany
}

\begin{abstract}
Analysis of gene transcription patterns in complex tissues with multiple cell types is a major challenge. Examination of cellular subpopulations for molecular expression patterns requires their isolation from other surrounding cells. We performed single-cell mRNA analysis to study gangliogliomas obtained from patients with pharmacoresistant epilepsy $(n=6)$, in order to characterize CD34 expressing cells found in these tumors. Fresh-frozen biopsy tissue was analyzed by initial in situ-reverse transcription (in situ-RT) with oligonucleotides, subsequent immunohistochemistry (IHC) to identify specific cell types, and laser-capture microdissection (LCM, herein termed immuno-LCM) to obtain antigen-expressing cell subpopulations. Isolated complementary DNAs (cDNAs) were then quantified by real time-polymerase chain reaction (RT-PCR). We found that short- vs long-term incubation time for the IHC step did not adversely affect CDNA abundance obtained by subsequent RT-PCR, either for high-abundance (glyceraldehyde dehydrogenase; GAPDH), medium-abundance (glial fibrillary acidic protein; GFAP), or low abundance (neurofilament; NFM) gene transcripts. We also determined that the cellular specificity of capture was excellent, as determined by lack of contamination between different immuno-LCM cell isolates. We were therefore able to examine the lineage expression markers of isolated CD34expressing cells. We observed coexpression of CD34 and NFM, suggesting neuronal differentiation of the CD34 expressing cellular elements in gangliogliomas. Expression markers for other cellular types (myelin basic protein for oligodendroglia; GFAP for astrocytes) were negative. Our findings support the hypothesis that gangiogliomas contain neuronal elements with compromised or atypical differentiation. We consider that this in situ-RT/immuno-LCM protocol is of general applicability, whereby virtually any primary antibody can be used to facilitate capture of individual cells in tissue sections for molecular analysis.

Laboratory Investigation (2004) 84, 1520-1525, advance online publication, 16 August 2004; doi:10.1038/labinvest.3700165
\end{abstract}

Keywords: in situ-reverse transcription; immunohistochemistry; laser microdissection; real-time RT-PCR; ganglioglioma

Cellular resolution of transcription patterns constitutes a major challenge for gene expression analyses in tissues with complex histoarchitecture such as the brain. Laser capture microdissection (LCM) allows the isolation of individual cells from heterogeneous tissue samples and subsequent gene expression analysis. ${ }^{1,2}$ Starting from individual neuroepithelial cells, mRNA analyses by reverse transcription-polymerase chain reaction (RT-PCR) ${ }^{3}$ and even genomewide expression profiling have

Correspondence: Dr AJ Becker, MD, Department of Neuropathology, University of Bonn Medical Center, Sigmund-Freud Str. 25, 53105 Bonn, Germany.

E-mail: albert_becker@uni-bonn.de

Received 27 May 2004; revised 12 July 2004; accepted 12 July 2004; published online 16 August 2004 been reported..$^{4-7}$ With respect to the identification of target cells for laser isolation, the microscopic discrimination of specific cell types in routinely stained tissue sections relies largely on parameters such as cellular size and shape. LCM from immunostained tissue sections enables significantly more specific access to cells of interest. However, a limiting factor for the combination of immunohistochemistry (IHC) and LCM (Immuno-LCM) is the instability of mRNA. Recent reports describing mRNA analysis from immunostained cells describe rapid protocols for Immuno-LCM in the range of minutes. ${ }^{8-10}$ However, the majority of antibodies require extensive IHC-protocols, often with overnight incubation. In situ-transcription was originally established as procedure for reverse transcription of mRNAs and generation of radiolabeled cDNAs in 
fixed tissue sections. ${ }^{11}$ Here, we describe a procedure composed of initial in situ-RT with oligonucleotides, subsequent IHC and LCM, followed by (real-time) PCR-based expression analysis. The protocol is then applied to study the cellular nature of frequent epilepsy-associated tumors. However, the protocol can be combined with virtually any primary antibody, suggesting it is also suitable for diagnostic use.

Gangliogliomas constitute epilepsy-associated, highly differentiated biphasic tumors, composed of neoplastic glial and dysplastic neuronal elements. Intriguingly, gangliogliomas express the stem cell epitope CD $34,{ }^{12}$ suggesting an origin from a developmentally compromised precursor lesion. However, the cellular identity of CD34 expressing elements remains enigmatic. ${ }^{12}$ However, CD34 expression has been also described in activated microglia, ${ }^{13,14}$ cellular elements frequently observed in brain tissue following epileptic attacks. In order to characterize the cellular origin of CD34-expressing cells in gangliogliomas, we employed in situ-RT primers specific for three neural lineage markers: glial fibrillary acidic protein (GFAP), neurofilament (NFM) and myelin basic protein (MBP); as well as human leukocyte antigen (HLA-DQ) and CD34.

\section{Methods and results}

\section{Tissue}

Biopsy samples were obtained from patients with chronic pharmacoresistant TLE in the Epilepsy Surgery Program at Bonn University $(n=6$ : Table 1). Surgical removal of tumors was necessary to achieve seizure control in all cases. ${ }^{15}$ Informed, written consent was obtained from all patients for additional studies. Procedures were carried out in accordance with the Helsinki-Declaration and approved by the local ethics committee.

Fresh frozen tissue was cut into $10 \mu \mathrm{m}$ sections, mounted on poly-L-lysine coated membrane-covered glass slides and air-dried for $30 \mathrm{~min}$. Slides were fixed in $4 \%$ PFA/PBS (pH 7.4) at $4^{\circ} \mathrm{C}$ for $10 \mathrm{~min}$ and washed. All wash steps were carried out for $2 \times 5 \mathrm{~min}$ in PBS at room temperature. The mRNA was denatured by stirring for $10 \mathrm{~min}$ in $0.1 \mathrm{M}$ TEA $(+\mathrm{NaCl})(\mathrm{pH} 8.0)$ and two applications of $0.5 \%$ acetic anhydride. After washing, slides were treated with $0.1 \%$ Triton/PBS for $20 \mathrm{~min}$ to permeabilize the membranes, which was followed by another wash.

The histopathology of a ganglioglioma is shown in Figure 1(1), demonstrating the typical biophasic pattern of neoplastic glial and dysplastic neuronal elements. Cellular expression of the stem cell epitope CD34 also is demonstrated, raising the question under study as to their specific nature. Accordingly, fresh frozen tissue was cut.

\section{In Situ-RT}

For in situ-RT, ${ }^{11}$ RT-mix (MBI Fermentas) containing $8 \mu \mathrm{l} 5 \times$ reaction buffer, $2 \mu \mathrm{l}$ ribonuclease inhibitor $(20 \mathrm{U} / \mu \mathrm{l}), 4 \mu \mathrm{l}$ dNTPs $(10 \mathrm{mM}$ each), $4 \mu \mathrm{l}$ reverse transcriptase $(200 \mathrm{U} / \mu \mathrm{l}), 2 \mu \mathrm{l}$ of each reverse primer (10 pmol) (Table 2) and $18 \mu \mathrm{l}$ DEPC-water were placed on individual slides. Primers were designed mRNA-specific by primer express software (Applied Biosystems). All procedures were carried out under RNase-free conditions. We then positioned a coverslip on the sections, which were transferred to a humid box. Mixes of the primers specific for abovementioned genes were used. The primers were modified by a nonspecific tail for concatamerization, for example, 5'-CCC CAA ACC CCA AAC CCC$3^{\prime}$ and $5^{\prime}$-GGG GTT TGG GGT TTG GGG-3'. This modification provides a network of generated cDNAs and avoids their displacement ${ }^{16}$ resulting in a high specificity of signals. Slides were incubated at $4^{\circ} \mathrm{C} 1 \mathrm{~h}$, followed for $2 \mathrm{~h}$ at $37^{\circ} \mathrm{C}$. After washing and gentle removal of the coverslips, slides were fixed in $4 \% \mathrm{PFA} / \mathrm{PBS}$ (pH7.4) at $4^{\circ} \mathrm{C}$ for $10 \mathrm{~min}$.

\section{IHC}

Initially, we aimed to study potential degeneration of templates dependent on variation of incubation times in primary antibody. Therefore, we carried out real-time RT-PCR quantification of high, intermediate and low copy transcripts (GAPDH, GFAP and NFM) in tissue sections subjected to IHC for short vs

Table 1 Clinical parameters of patients used in the present study

\begin{tabular}{rccccrr}
\hline ID & Age (years) & Lesion & Sex & Seizure type & Duration & Onset \\
\hline 1 & 15 & GG (WHO Grade I) & M & CPS & 14 & 1 \\
2 & 29 & GG (WHO Grade I) & M & SPS, CPS with sGTCS & 26 & 3 \\
3 & 29 & GG (WHO Grade I) & F & CPS & 23 & 60 \\
4 & 24 & GG (WHO Grade I) & M & CPS, sGTCS & 4 & 28 \\
5 & 29 & GG (WHO Grade I) & F & CPS & 17 & 12 \\
6 & 36 & GG (WHO Grade I) & F & SPS, CPS & 34 & 3 \\
\hline
\end{tabular}

ID, identification number; GG, ganglioglioma; F, female; M, male; SPS, simple partial seizures; CPS, complex partial seizures; sGTCS, secondary generalized tonic clonic seizures; ND = not determined. Duration and onset of epileptic seizures is given in years; frequency of seizures refers to number of events per month. 
1 a
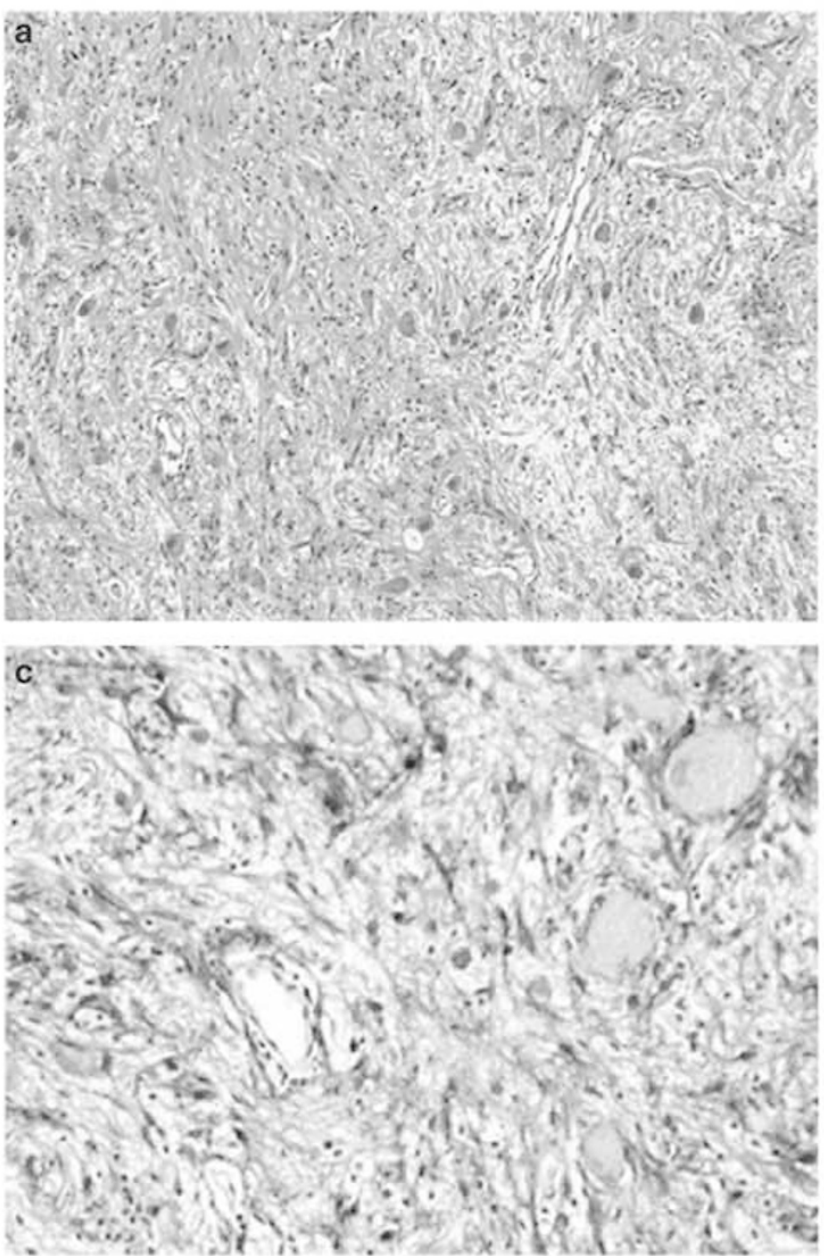

2 a

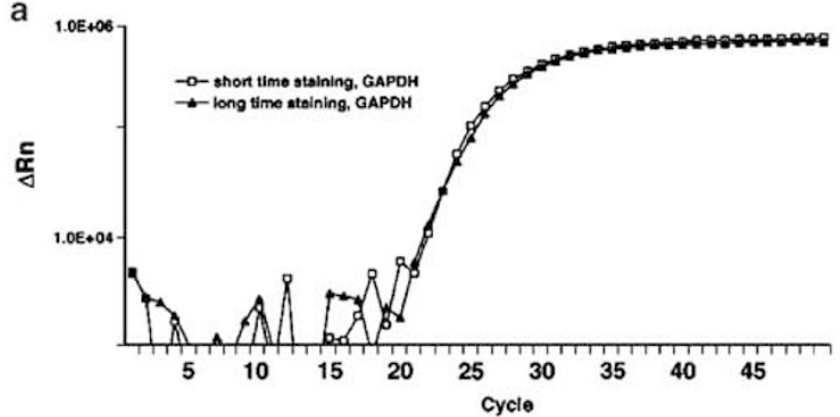

C

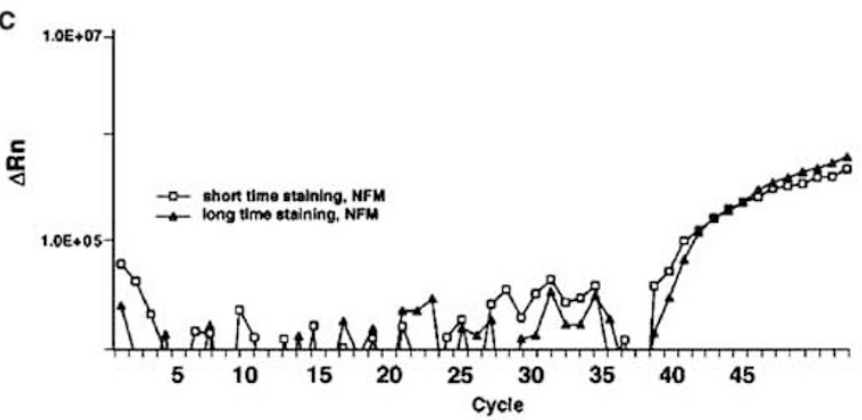

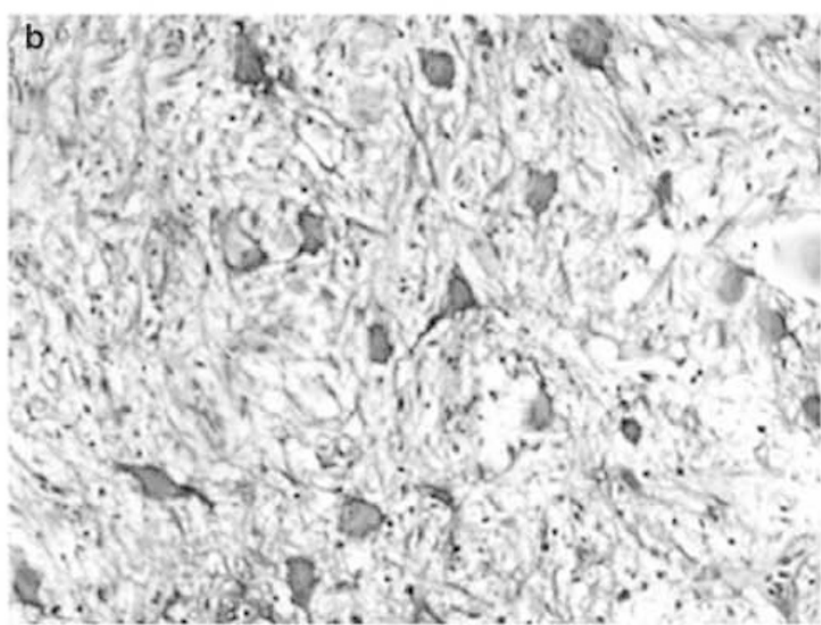
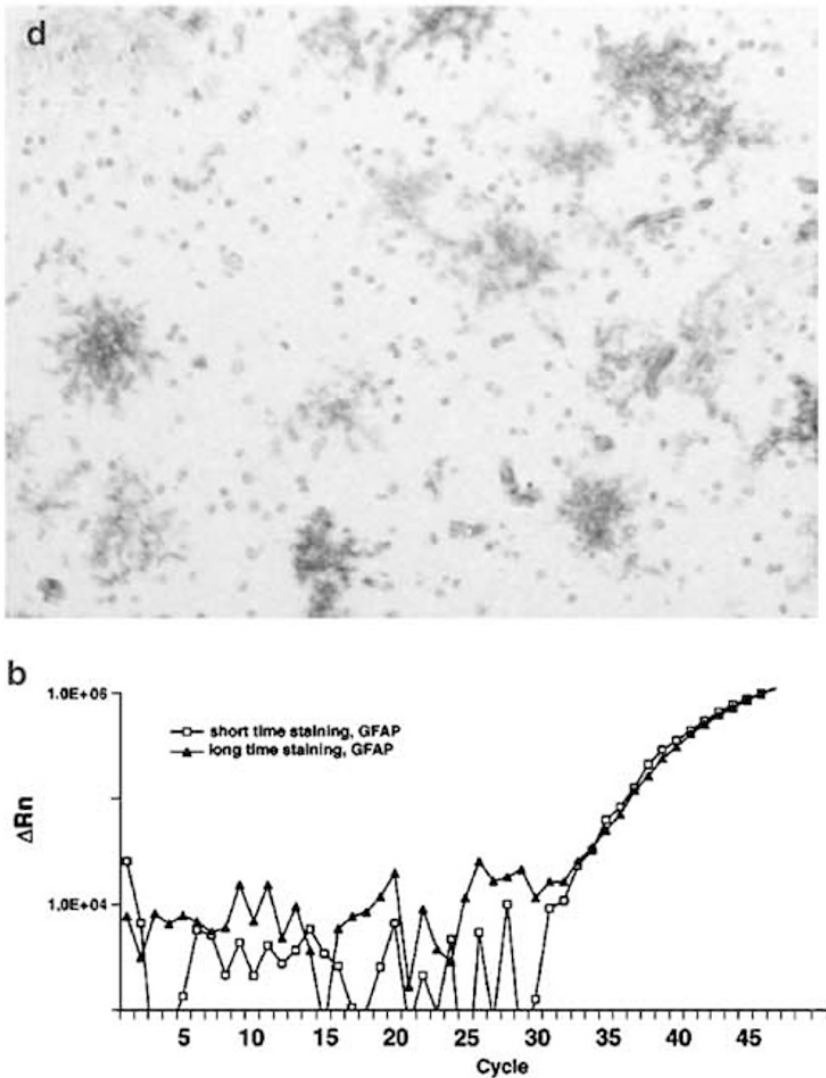
long incubation times. After in situ-RT, ${ }^{11}$ slides were immunostained with mouse monoclonal antibodies directed against human GFAP or CD34. The IHC experiments with the shorter incubation time started with a blocking step (PBS with 10\% FCS, 2\% NHS, nonfat dry milk) for $30 \mathrm{~min}$ at $37^{\circ} \mathrm{C}$. Primary antibodies (GFAP, DAKO, 1:400; CD34, Immunotech, ready to use) were then added, and slides are incubated at $37^{\circ} \mathrm{C}$ for $15 \mathrm{~min}$ (CD34) or $45 \mathrm{~min}$ (GFAP). After washing in PBS $(2 \times 2 \mathrm{~min})$, slides were covered with biotinylated second antibody antimouse IgG (Vector Laboratories) (1:100, PBS with $10 \%$ FCS) and incubated at $37^{\circ} \mathrm{C}$ for $15 \mathrm{~min}$, followed by washing $(2 \times 2 \mathrm{~min})$ and a $15 \mathrm{~min}$ incubation at $37^{\circ} \mathrm{C}$ with $\mathrm{AB}$ complex (Vector Laboratories). The stains were developed by $\mathrm{DAB}$ application $(0.05 \mathrm{M}$ Tris/HCl pH7.4 with DAB 1:50, $\mathrm{H}_{2} \mathrm{O}_{2}$ 1:2000) after washing $(2 \times 2 \mathrm{~min})$. For the IHC experiments with the longer incubation time, the following modifications were made: the blocking step was carried out for $1.5 \mathrm{~h}$ at $37^{\circ} \mathrm{C}$ and followed by overnight incubation with primary antibody at room temperature. The second antibody (1:200, PBS with $10 \%$ FCS) was applied for $2 \mathrm{~h}$ at $37^{\circ} \mathrm{C}$, followed by $2 \mathrm{~h} \mathrm{AB}$ complex.

\section{LCM and RT-PCR}

UV-Laser microbeam technology (PALM, Bernried) was applied for microdissection and separate harvesting of immunostained neurons, glial cell components and blood vessels in gangliogliomas. For cDNA isolation of laser microdissected cells, the DNeasy tissue kit was used according to the manufacturer's guidelines (Qiagen, Hilden). By real-time PCR, we quantified target mRNAs derived from identical areas of adjacent ganglioglioma sections containing several hundred cells, which we had previously been subjected to IHC. Real-time RT-PCR (ABI PRISM 7700) was carried out in a $13 \mu \mathrm{l}$ reaction volume containing $6.25 \mu \mathrm{l}$ SYBR Green PCR Master Mix (Applied Biosystems), $0.375 \mu$ l forward and reverse primers $(10 \mathrm{pmol} / \mu \mathrm{l}), 3.0 \mu \mathrm{l}$ DEPC- $\mathrm{H}_{2} \mathrm{O}$ and cDNA dissolved in $2.5 \mu \mathrm{l}$ DEPC- $\mathrm{H}_{2} \mathrm{O}$. Duplicate reactions were carried out for each gene. After preincubation for $10 \mathrm{~min}$ at $95^{\circ} \mathrm{C}$, we performed 50 PCR cycles $\left(20 \mathrm{~s}\right.$ at $94^{\circ} \mathrm{C}$ followed by $30 \mathrm{~s}$ at $59^{\circ} \mathrm{C}$, and $40 \mathrm{~s}$ at $72^{\circ} \mathrm{C}$ ). The SYBR Green fluorescence signal was measured in each cycle.

Real-time PCR revealed significant differences in the levels of GAPDH (high abundance), GFAP (medium abundance) and NFM (low abundance) after in situ-RT and IHC with a CD34 antibody. When short- vs long-time IHC were compared, there were no significant differences in the cDNA levels detected (Figure 1(2)a-c). This finding suggests that cDNAs were quantitatively conserved after in situ$\mathrm{RT}$, independent of variation of IHC.

\section{Cellular Specificity}

Next, we addressed the cellular specificity of the RTPCR signals, that is, whether cDNAs after in situ-RT were anchored in the cells of origin during IHC. We used tissue sections after in situ-RT and immunostained for GFAP/CD34. After LCM isolation of

Table 2 Primer sequences, annealing temperatures and $\mathrm{MgCl}_{2}$ concentrations of the genes under study

\begin{tabular}{|c|c|c|c|c|}
\hline Gene & Forward primer & Reverse primer & $\begin{array}{c}\text { Annealing } \\
\text { temeprature } \\
\left({ }^{\circ} \mathrm{C}\right)\end{array}$ & $\begin{array}{c}\mathrm{MgCl}_{2} \\
\text { concentration } \\
(\mathrm{mM})\end{array}$ \\
\hline CD34 & $5^{\prime}$-CCCACAGGAGAAAGGCTGG-3' & $\begin{array}{l}5^{\prime} \text {-CCCAAACCCCAAACCCCTGAGCCCCTCGGTTCACA-3' } \\
5^{\prime} \text {-GGGTTTGGGGTTTGGGGTGAGCCCCTCGGTTCACA-3' }\end{array}$ & 55 & 1.0 \\
\hline GAPDH & 5'-GAAGGTGAAGGTCGGAGT-3' & $\begin{array}{l}5^{\prime} \text {-CCCCAAACCCCAAACCCCGAAGATGGTGATGGGATTTC-3' } \\
5^{\prime} \text {-GGGGTTTGGGGTTTGGGGGAAGATGGTGATGGGATTTC-3 }\end{array}$ & 55 & 1.0 \\
\hline GFAP & 5'-AGAACCGGATCACCATTCCC-3' & $\begin{array}{l}5^{\prime} \text {-CCCCAAACCCCAAACCCCCTCTCCATCCCGCATCTCC-3' } \\
5^{\prime} \text {-GGGGTTTGGGGTTTGGGGCTCTCCATCCCGCATCTCC-3' }\end{array}$ & 60 & 1.0 \\
\hline MBP & 5'-GCAGATTTAGCTGGGGGGC-3' & $\begin{array}{l}5^{\prime}-\text {-CCCCAAACCCCAAACCCCCGACTATCTCTTCCTCCCAGCTTA-3' } \\
5^{\prime} \text {-GGGGTTTGGGGTTTGGGGCGACTATCTCTTCCTCCCAGCTTA-3' }\end{array}$ & 55 & 1.0 \\
\hline NFM & 5'-CAGGACACCATCCAGCAGCT-3' & $\begin{array}{l}5^{\prime} \text {-CCCCAAACCCCAAACCCCCTCCAGGAGTTTTCTGTACGCAG-3' } \\
5^{\prime} \text {-GGGGTTTGGGGTTTGGGGCTCCAGGAGTTTTCTGTACGCAG-3' }\end{array}$ & 55 & 1.5 \\
\hline HLA-DQ & 5'-ATGACTGCAAGGTGGAGCACT-3' & $\begin{array}{l}5^{\prime} \text {-CCCCAAACCCCAAACCCCGCAGGCCTTGGATGATGAAG-3' } \\
5^{\prime} \text {-GGGGTTTGGGGTTTGGGGGCAGGCCTTGGATGATGAAG-3' }\end{array}$ & 60 & 1.5 \\
\hline
\end{tabular}

GenBank ID: CD34: XM_036615; GAPDH: BC023632; GFAP: J04569; MBP: M13577; NFM: XM_005158; HLA-DQ: NM_002122

The conditions were used for in situ-RT, PCR and quantitative RT-PCR. Underlined sequences display a nonspecific tail for concatamerization.

Figure 1 (1) (a-d) Histopathology of a ganglioglioma (a: hematoxylin and eosin (H\&E) stain; $\times 20$ ) with the typical biphasic pattern composed of neoplastic glial (b: GFAP IHC, $\times 40$ ) and dysplastic neuronal elements (c: synaptophysin IHC, $\times 40)$. (d) Cellular elements expressing the stem cell epitope CD34 in a 'satellitosis'-like pattern can be observed as ganglioglioma components (CD34 IHC, $\times 40)$. (2) (a-c) Comparison of amplification plots (normalized fluorescent signal $\left(\Delta R_{\mathrm{n}}\right)$ vs PCR cycles) after in situ-RT and CD34 short- (open symbols) vs long time- (closed symbols) IHC. During real-time PCR, products were labeled by SYBR Green. There were no significant differences in cDNA abundance after short/long-term IHC in the high (2a, GAPDH), intermediate (2b, GFAP), and low (2c, NFM) transcript copy range. 
a

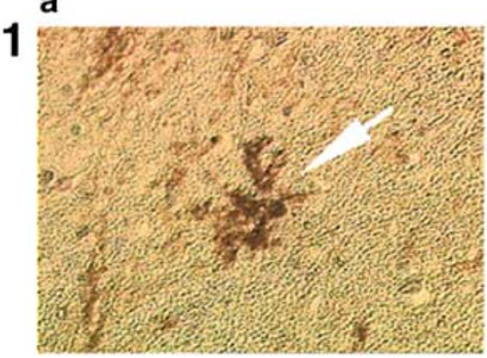

2

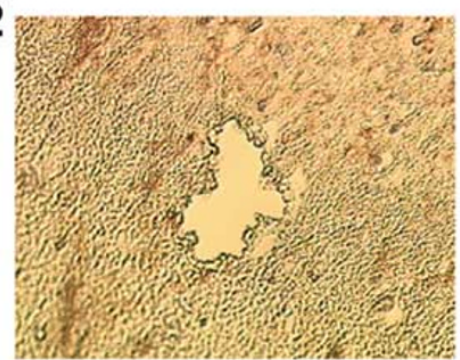

\section{b}
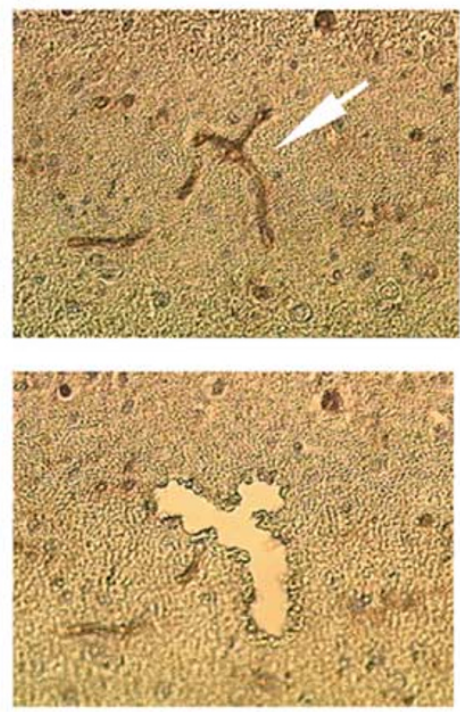

C
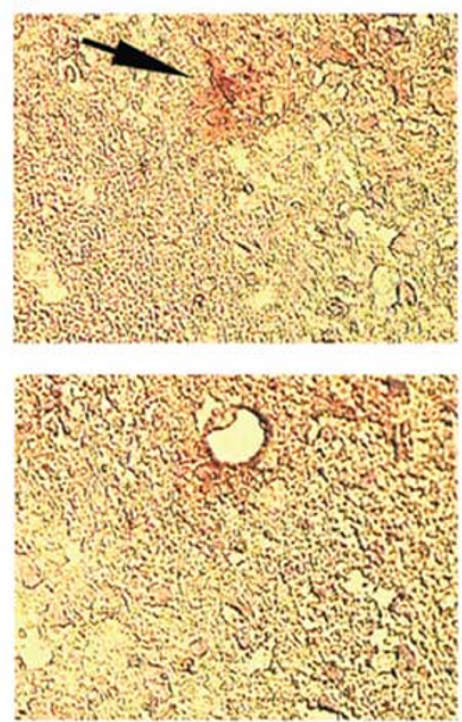

\section{3}
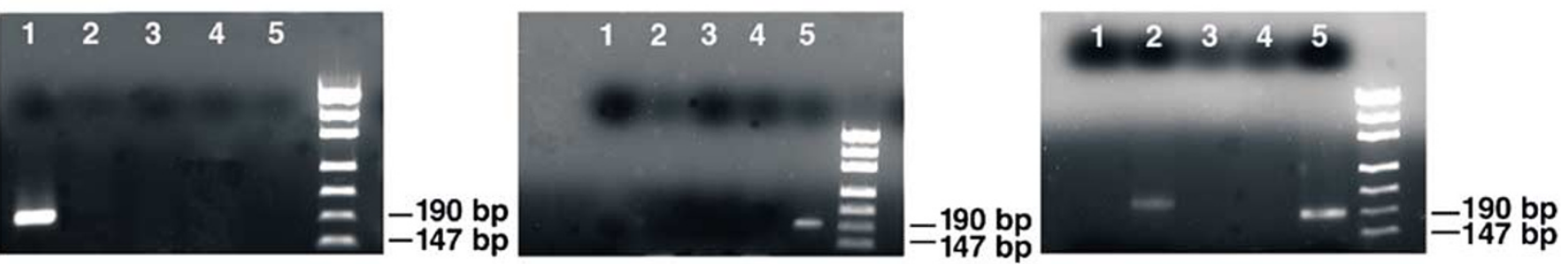

Figure 2 Ganglioglioma sections $(1,2)$ after in situ-RT and IHC with antibodies against GFAP (a) and CD34 (b, c). a1-3: After LCM of a GFAP expressing cell (white arrow in a1; a2), a PCR product was only observed for GFAP in lane 1 (a3) on the agarosis gel (lane 1: GFAP, lane 2: NFM, lane 3: MBP, lane 4: HLA-DQ, lane 5: CD34). Following LCM of CD34 expressing blood vessel components (white arrow in B1; B2), an amplicon was obtained only for CD34 in lane 5 (b3). In c1-2, representative laser microdissection of a CD34 expressing cell component within a ganglioglioma was shown (black arrow in c1). PCR products for NFM (lane 2) and CD34 (lane 5) were obtained from laser microdissected, CD34 immunoreactive cells after in situ-RT (c3).

CD34-positive blood vessel endothelia and individual GFAP-expressing astrocytes, PCR was carried out as described above. For PCR amplification, a final volume of $10 \mu \mathrm{l}$ contained $1.0 / 1.5 \mathrm{mM} \mathrm{MgCl}{ }_{2}$ (50 mM), 5.75/5.65 $\mu \mathrm{l} \mathrm{H}$ $\mathrm{O}, 1 \mu \mathrm{l} 10 \times$ PCR buffer, $1 \mu \mathrm{l}$ dNTPs ( $2 \mathrm{mM}$ each), $0.5 \mu \mathrm{l}$ of each primer $(10 \mathrm{pmol} /$ $\mu \mathrm{l}), 0.05 \mu \mathrm{l}$ Taq polymerase and $1 \mu \mathrm{l}$ cDNA template. After initial denaturation at $94^{\circ} \mathrm{C}$ for $5 \mathrm{~min}, 35$ PCR cycles were at $94^{\circ} \mathrm{C}$ for $30 \mathrm{~s}, 55 / 60^{\circ} \mathrm{C}$ for $40 \mathrm{~s}$ and $72^{\circ} \mathrm{C}$ for $1 \mathrm{~min}$, and $72^{\circ} \mathrm{C}$ for $10 \mathrm{~min}$ (Table 2). PCR products were visualized by gel electrophoresis in $2 \%$ agarose gels. These experiments revealed a high specificity of transcripts after Immuno-LCM, that is, only GFAP transcripts were found in GFAP immunolabeled astrocytes (Figure 2a1-3). We observed CD34 transcripts only in CD34-immunoreactive endothelial cells from blood vessels (Figure 2b13 ). No contaminating PCR products were detected for NFM, HLA-DQ and MBP.

\section{Lineage}

Based on these experiments, we addressed the lineage marker expression pattern of CD34-positive cells in gangliogliomas. After in situ-RT with primers for GFAP, NFM, MBP, HLA-DQ and CD34, ganglioglioma sections were immunostained for CD34. PCR was carried out as described above. We observed coexpression of CD34 and NFM, suggesting neuronal differentiation of CD34 expressing cellular elements in gangliogliomas $(n=6$; all experiments in duplicates; Figure 2c1-3). We found no expression of the oligodendroglial marker MBP, the astrocytic marker GFAP, or HLA-DQ in CD34positive ganglioglioma elements (Figure 2c1-3). These data suggest neuronal characteristics of CD34 expressing ganglioglioma cell components. Considering the role of CD34 as stem cell epitope, these findings support the hypothesis that gangliogliomas contain neural elements with compromised or atypical differentiation. ${ }^{12}$

\section{Conclusion}

In summary, the combination of in situ-RT and immuno-LCM provides the ability to carry out gene expression studies by PCR after LCM of tissue sections immunostained with antibody under vary- 
ing conditions of IHC. As shown here, fresh frozen tissue was suited as starting material for this protocol. Considering the fact that fresh frozen tissue samples are generally the first biopsy tissue samples available after surgery, this protocol might be well used in diagnostic molecular-pathological settings. Also, the combination of several primers in the same in situ-RT reaction- 5 primers applied so far-suggests a high flexibility of the method. By modification of the in situ-RT primers, that is, attachment of a T7 RNA polymerase recognition site, the described procedure can also be combined with mRNA profiling. ${ }^{17}$ It may also be applied to paraffin-embedded tissue, ${ }^{5}$ which could be useful, considering potential difficulty in obtaining nondisease control tissue from human fresh frozen biopsy specimens. In conclusion, the present protocol provides a fast and easy procedure for gene expression analysis after Immuno-LCM.

\section{Acknowledgements}

We thank Ingmar Blümcke (Department of Neuropathology, University of Erlangen) for critical discussions. Our work is supported by DFG (TR3), BMBF (NGFN) and BONFOR.

\section{References}

1 Schütze K, Lahr G. Identification of expressed genes by laser-mediated manipulation of single cells. Nat Biotechnol 1998;16:737-742.

2 Feng Y, Walsh CA. Protein-protein interactions, cytoskeletal regulation and neuronal migration. Nat Rev Neurosci 2001;2:408-416.

3 Becker AJ, Chen J, Paus S, et al. Transcriptional profiling in human epilepsy: expression array and single cell real-time qRT-PCR analysis reveal distinct cellular gene regulation. Neuroreport 2002;13:1327-1333.

4 Van Gelder RN, von Zastrow ME, Yool A, et al. Amplified RNA synthesized from limited quantities of heterogeneous cDNA. Proc Natl Acad Sci USA 1990;87:1663-1667.

5 Crino PB, Trojanowski JQ, Dichter MA, et al. Embryonic neuronal markers in tuberous sclerosis: single-cell molecular pathology. Proc Natl Acad Sci USA 1996; 93:14152-14157.

6 Eberwine J, Yeh H, Miyashiro K, et al. Analysis of gene expression in single live neurons. Proc Natl Acad Sci USA 1992;89:3010-3014.

7 Eberwine J, Spencer C, Miyashiro K, et al. Complementary DNA synthesis in situ: methods and applications. Methods Enzymol 1992;216:80-100.

8 Fink L, Kinfe T, Stein MM, et al. Immunostaining and laser-assisted cell picking for mRNA analysis. Lab Invest 2000;80:327-333.

9 Fink L, Kinfe T, Seeger W, et al. Immunostaining for cell picking and real-time mRNA quantitation. Am J Pathol 2000;157:1459-1466.

10 Fend F, Emmert-Buck MR, Chuaqui R, et al. ImmunoLCM: laser capture microdissection of immunostained frozen sections for mRNA analysis. Am J Pathol 1999;154:61-66.

11 Tecott LH, Barchas JD, Eberwine JH. In situ transcription: specific synthesis of complementary DNA in fixed tissue sections. Science 1988;240:16611664.

12 Blümcke I, Giencke K, Wardelmann E, et al. The CD34 epitope is expressed in neoplastic and malformative lesions associated with chronic, focal epilepsies. Acta Neuropathol 1999;97:481-490.

13 Hess DC, Abe T, Hill WD, et al. Hematopoietic origin of microglial and perivascular cells in brain. Exp Neurol 2004;186:134-144.

14 Asheuer M, Pflumio F, Benhamida S, et al. Human CD34+ cells differentiate into microglia and express recombinant therapeutic protein. Proc Natl Acad Sci USA 2004;101:3557-3562.

15 Kral T, Clusmann H, Urbach J, et al. Preoperative evaluation for epilepsy surgery (Bonn Algorithm). Zentralbl Neurochir 2002;63:106-110.

16 Behrens P, Rothe M, Wellmann A, et al. The Ets-1 transcription factor is up-regulated together with MMP 1 and MMP 9 in the stroma of pre-invasive breast cancer. J Pathol 2001;194:43-50.

17 Eberwine J. Single-cell molecular biology. Nat Neurosci 2001;4:1155-1156. 